\title{
The Factors Which Influence Accounting Student's Understanding with Spiritual Intelligence as Moderating Variable (An Empirical Study on the student of USU, UNIMED, and UINSU)
}

\author{
Khanti Listya \\ Departement of Accounting \\ Universitas Sumatera Utara \\ Medan, Indonesia \\ khantilistya@gmail.com
}

\author{
Erwin Abu Bakar \\ Departement of Accounting \\ Universitas Sumatera Utara \\ Medan, Indonesia
}

\author{
Idhar Yahya \\ Departement of Accounting \\ Universitas Sumatera Utara \\ Medan, Indonesia \\ idharyahya@yahoo.co.id
}

\begin{abstract}
The objective of the research was to analyze the factors influencing accounting students to understand accounting with spiritual quotient as the moderating variable (an empirical study on Students of University of Sumatera Utara (USU), State University of Medan (UNIMED), and State Islamic University of Sumatera Utara (UINSU)). This is a causal associative research. The population of the research was 458 students majoring in accounting. The samples were determined by cluster random sampling method and taken by using incidental random sampling technique. The samples were determined by proportional calculation. The data were primary data obtained through questionnaires from 139 respondents consisting of 69 accounting students from USU, 47 accounting students from UNIMED and 23 sharia accounting students from UINSU. The data were analyzed using multiple regression analysis method and residual testing. The results showed that self-recognition, self-control, motivation, empathy, social skills, and learning behavior simultaneously had a significant positive influence on USU, UNIMED and UINSU students to understand of accounting. Partially, self-recognition, self-control, motivation, empathy, and social skill did not have any influences on USU, UNIMED and UINSU students to understand accounting while learning behavior had a significant influence on USU, UNIMED, and UINSU students to understand accounting. Spiritual quotient was the moderating variable that could strengthen the correlation of self-recognition, self-control, motivation, empathy, social skill, and learning behavior with USU, UNIMED and UINSU students to understand accounting.
\end{abstract}

Keywords-Accounting Understanding; Self-recognition; Selfcontrol; Motivation; Empathy; Social Skill; Learning Behavior; Spiritual Quotient

\section{INTRODUCTION}

Accounting education held in college is intended to educate students to have the competence as a professional accountant. The universities should continuously improve the quality of their education system to produce qualified graduates [1]
The factors can support the success of accounting education are the self attitude, mental and personal aspects of students in developing his personality. This is related to the Emotional Quotient

Our school and culture focus more on academic ability, ignoring emotional intelligence. The most educational programs based only on intellectual intelligence only, even tough the intellectual intelligence we need to know how to develop the emotional intelligence, such as toughness, initiative, optimism, adaptability that now become the basis of a new assessment. Today many of us find educated people and look so convincing, but his career is stunted or worse, knocked out, due to their low emotional intelligence.

The results of Daniel Goleman [2] show that intellectual intelligence contributes only 20 percent to the success of one's life. Meanwhile, 80 percent depends on emotional intelligence, social intelligence, and spiritual intelligence, even in terms of work success, intellectual intelligence only contributes 4 percent. According to Suprianto [3], emotional intelligence has a positive and significant influence on students' accounting understanding (UNNES and UNDIP), private universities (UNISSULA), where the better the students' emotional intelligence aspect is, the better the students' accounting understanding has.

Similarly, research conducted by Ghofur [4] that emotional intelligence consists of several variables such as selfrecognition, self-control, motivation, empathy and social skills also have the positive and significant impact on students' accounting understanding at two private universities in Lamongan, Islamic University Lamongan and the Islamic University of Darul 'Ulum.

Based on previous researches and the phenomenon, it is important for colleges to improve students' emotional intelligence to understand what they get in the learning process during the lecture to prepare students to be ready to work in the 
future. To understand accounting not only needs emotional intelligence but also requires good learning behavior.

Therefore, researcher became more interested in researching emotional intelligence consisting of several variables (self-recognition, self-control, motivation, empathy and social skills) and learning behavior as one of the aspects that affect student accounting understanding. The researcher will re-observe the effects of emotional intelligence consisting of several variables (self-recognition, self-control, motivation, empathy and social skills) and learning behavior on students' accounting understanding in USU, UNIMED, and UINSU.

\section{THE LITERATURE ANDDEVELOPMENT OF HYPOTHESES}

\section{A. Theoretical Framework}

\section{1) Rogers' theory}

Rogers' theory bases himself on the tendency of each individual to evaluate all his experiences in terms of his selfconcept: "I", "who am I", "what can I do and more. Each individual has an ideal self-image (ideal self) [5].The ability to discover the real self will develop themselves to become better. This concept of self-recognition is very important in person, whereby knowing himself well everyone will do what he likes, know what he doesn't like, not only that someone will be able to recognize which talent he will develop.

\section{2) Achievement Motive Theory}

According to David McClelland in Jamaris [6] said that achievement motivation is a motivation that makes the individual trying to get the achievement of the activities he does and tries to overcome all the obstacles that hinder his efforts to get the achievement.

\section{B. Accounting Understanding}

Suwardjono [7] said, accounting knowledge can be viewed from two sides of understanding that are as knowledge profession (expertise) practiced in the real world and as well as a discipline of knowledge taught in college. Accounting as an object of knowledge in universities has two areas of study, practical and theoretical field. Where accounting theory can not be separated from the practical accounting itself because the main purpose is to explain the current accounting practices and provide the basis for the practical development. Accounting tends to be developed on the basis of value judgment, which is met by environmental factors in which accounting is practiced.

According to Melandy and Aziza [8], understanding of accounting is an ability of person to know and understand about accounting. This accounting understanding can be measured from the value of the course which includes Introduction to Accounting, Medium Financial Accounting 1, Medium Financial Accounting 2, Advanced Financial Accounting 1, Advanced Financial Accounting 2, Auditing 1, Auditing 2, Auditing 3, and Accounting Theory. They are elements that describe the accounting generally.

From the above definition, the understanding of accounting is a situation where there is already a deep understanding and understanding of accounting that will be able to produce information that can be used where the assessment is measured by the value of certain courses including Accounting Theory, Financial Accounting, Management Accounting and Auditing.

\section{Emotional intelligence}

Jamaris [6] through his writing describes the emotional intelligence developed by Goleman that emotional intelligence is strongly related to the concepts of affection or caring each other and spiritual that must be exist in the working life as well as multiple intelligences. EQ consists of the following five domains:

1. Knowing your emotions or understanding of your own emotions

2. Managing your own emotions

3. Motivating yourself

4. Recognising and understanding other people's emotions

5. Managing relationships, managing relationships with others that can be done by understanding the feelings of others or empathy

\section{Self Recognition}

Self Recognition is a knowledge of person's ability to know inner feelings and is used to make decisions for himself, has realistic benchmarks of self-ability and strong self-confident. Good student recognition skills are needed in learning activities. Every student should be able to recognize what he feels when learning, what he likes, and of course what he aspires to. Thus the student will develop himself according to what he feels.

\section{E. Self-control}

Emotional control does not mean avoiding unpleasant feelings to be happy and in a stable condition, but not letting yourself out of control in unpleasant feelings that erase pleasant things. Self-control is the ability to handle the emotions to become a positive impact, sensitive to conscience, able to control the enjoyment before the achievement of a goal, and able to recover from emotional pressure.

\section{F. Motivation}

Motivation is the ability to use the desire to the spirit and energy to achieve a better state, and able to take the initiative and act effectively. Every individual in doing something, of course, has certain motives especially a student. With a logical attitude and understand the results of his actions, a student usually has certain motives in the actions daily, especially in the lecture, one of them is the motivation for achievement.

\section{G. Empathy}

Empathy in oneself will make someone able to feel what others feel and can place himself as someone else. Attitude sensitive to the feelings of others greatly affects every human action, especially in the learning process. Empathy is needed in learning activities because someone who able to feel what is felt by others will be more adaptable under certain conditions 
in learning and someone will be better to analyze the lessons he got.

\section{H. Social Skills}

Social skills are the ability to behave well when dealing with others, can influence, lead, deliberate, solve disputes, and work together in teams. The elements of social skills, namely influences, communication, conflict management, leadership, change catalyst, building relationships, collaboration and cooperation and team capabilities [9]

\section{Learning Behavior}

Learning behavior is often called learning habit, is an individual learning process repeatedly so that it becomes automatic or spontaneous. This behavior will affect the learning achievement. [7] According to Suwardjono good learning behavior consists of the habit of joining lectures, reading books, visiting library, facing exams. Learning Behavior, one of the habits to take lessons, in which taking the lesson will show formed patterns that shape the learning behavior. The habit of taking the lessons of the students can be demonstrated by being always present in lectures, prioritizing the interest of the lectures rather than other interests, striving to be present on time despite there are urgent interests and prepare the materials will be learned before lecturing.

\section{J. Spiritual Intelligence}

[6] Spiritual intelligence is ability used in order to solve problems daily. Robert Emons divides spiritual intelligence into five components:

1. The ability to transform something physically into transcendental.

2. Ability to emphasize the experiences had consciously

3. Ability to take daily blessings experience

4. Ability to be better

Spiritual intelligence has a deep understanding of the existence of this world which is ultimately absorbed in one's consciousness so that he has his own meaning in himself. The awareness of ourself relates to the facts that occur in our life that we feel there is a great power outside of ourselves that we can see through certain changes such as the existence of a disease, air, and human beings. Spiritual intelligence is not only related to mental ability but also related to something that is transcendental or unlogical of human ability and capability that leads to the Creator of the earth and everything in it that is God.

The spiritual intelligence in student himself will be seen from the student's ability to change something that is seen physically, to be a deeper meaning.

The logical relationship between the independent variable and the dependent variable is illustrated illustratively with the following conceptual research framework:

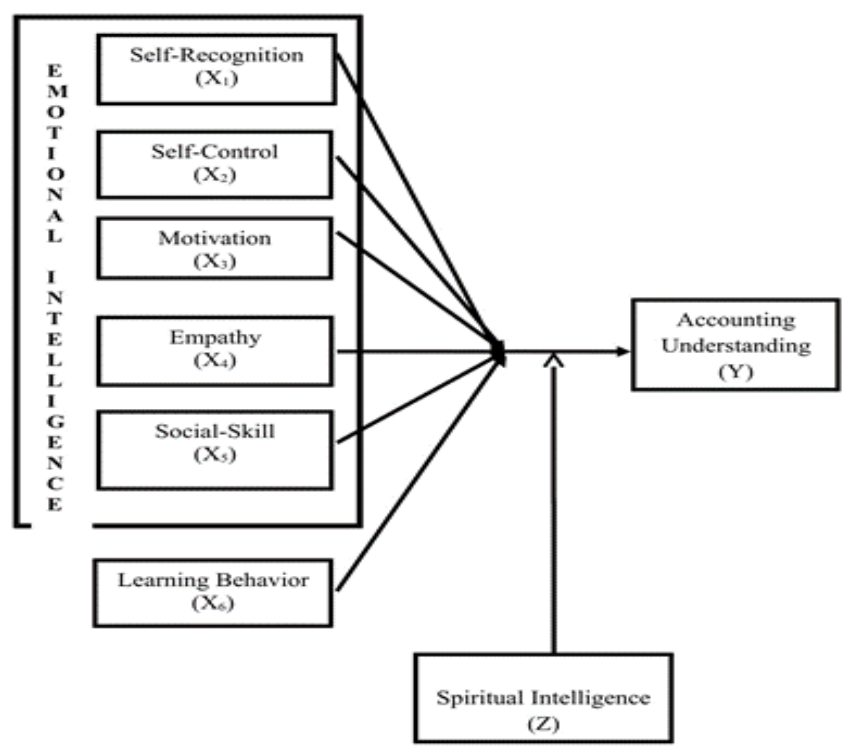

Figure 1

Concept Framework

Based on theoretical framework, it can be developed the following hypothesis:

1. Self-knowledge, self-control, motivation, empathy and social skills, and learning behaviors affect partially and simultaneously toward the understanding of student accounting in USU, UNIMED, and UINSU

2. Spiritual intelligence is able to moderate the relationship between self-recognition, self-control, motivation, empathy and social skills, and learning behavior toward student accounting understanding in USU, UNIMED, and UINSU

\section{METHODOLOGY}

This study was conducted on accounting students in this study USU, UNIMED, and UINSU population, and the population is 458 students. The sample calculation using Paul Leddy's formula obtained 139 samples. The data source in this research is the primary data and the measurement scale is the interval scale.

\section{A. Variable Operational Definition}

Accounting understanding is a situation which there are a deep understanding and understanding of accounting that will be able to produce information that can be used which the assessment is measured by the value of certain courses include, Introduction to Accounting, Financial Accounting, Management Accounting, Auditing, and Accounting Theory. Which the student score stated in the letters will be converted into numbers.

The introduction of a student is marked by how much ability can identify his or her will, goals and ideals to achieve. Good self-recognition will make person more understanding in determining what he or she will do. A good self-recognition will make the students more understand the purpose of life and what is aspired really. Not only recognizes what his purpose is, 
but also student can determine steps to achieve the goal so he reaches the desired goal.

Student self-control can be seen from how the student suppresses his emotions, act with the norms of the learning process and able to postpone certain things to achieve what he aspired to.

The motivation for a student is characterized by an eager attitude to take the lectures, the existence of goals and targets in the learning process, and of course the attitude to be better. Student motivation in teaching and learning process will make him more excited in the lecture.

Empathy is a feeling where we can feel what others feel. Can be able to understand the perspectives of others and generate trust relationships, and be able to align themselves with various types of individuals. By having empathy, he will make him in his live more balance and feel the existence of others. By having sensitivity to the condition, especially the process of teaching and learning so the students are able to harmonize what he will achieve.

Social skills shown by the attitude to work together with friends, organize, lead and deliberate will give impact in lecturing process especially in understanding material.

Behavioral learning can be demonstrated by the habits shown during the lectures and afterward while maintaining the intensity of learning.

Spiritual intelligence is an attitude that is shown with an optimistic attitude, believing there will be the strength that always with him in every learning process, able to get lessons from every learning process during the lecture.

\section{B. Data Analysis Method}

The method of data analysis used is multiple regression analysis by conducting the test includes descriptive statistics, classical assumption test. The model of the regression equation is:

$$
Y=a+b_{1} X_{1}+b_{2} X_{2}+b_{3} X_{3}+b_{4} X_{4}+b_{5} X_{5}+b_{6} X_{6}+e
$$

\section{Which are:}

$\mathrm{Y} \quad=$ Accounting understanding

$\mathrm{X}_{1} \quad=$ Self-Recognition

$\mathrm{X}_{2} \quad=$ Self-Control

$\mathrm{X}_{3} \quad=$ Motivation

$\mathrm{X}_{4} \quad=$ Empathy

$\mathrm{X}_{5} \quad=$ Social Skills

$\mathrm{X}_{6} \quad=$ Learning Behavior

a $\quad=$ Constant Number (price $\mathrm{Y}$, when $\mathrm{X}=0$ )

$\mathrm{e} \quad=$ Intolerable error $(5 \%)$

\section{RESEARCH RESULT AND DISCUSSION}

\section{A. Classical Assumption Testing}

\section{1) Normality Test Results}

The test results showed that the score of KolmogorovSmirnov is 0.553 and significant at 0.920 which the score is bigger than $\alpha=0.05$ so it can be concluded the residual data is distributed normally.

\section{2) Multicollinearity Test Results}

The multicollinearity test showed that the VIF score of each variable $\leq 10$, and the tolerance score $\geq 0.10$. It can be concluded that between the independent variables do not have multicollinearity symptoms.

3) Heteroskedasticity Test Results

Based on the Glejser test conducted shows that is sig score. All independent variables are more 0.05 , so it can be concluded that all independent variables do not heteroscedasticity symptoms.

\section{B. Results of Multiple Linear Regression Test}

From the results of multiple linear regressions testing can be arranged the regression equation as follows:

$\mathrm{Y}=13.917+0.060 \mathrm{X}_{1}-0.126 \mathrm{X}_{2}+0.010 \mathrm{X}_{3}+0.058 \mathrm{X}_{4}-$ $0.005 \mathrm{X}_{5}+0.175 \mathrm{X}_{6}$

Tabel 1. Multiple Linear Regression Tes Coefficients

\begin{tabular}{|c|c|c|c|c|c|}
\hline \multirow{2}{*}{ Model } & \multicolumn{2}{|c|}{$\begin{array}{c}\text { Unstandardized } \\
\text { Coefficients }\end{array}$} & $\begin{array}{c}\text { Standardized } \\
\text { Coefficients }\end{array}$ & \multirow{2}{*}{$\mathrm{t}$} & Sig. \\
\cline { 2 - 4 } & $\mathrm{B}$ & $\begin{array}{c}\text { Std. } \\
\text { Error }\end{array}$ & Beta & & \\
\hline $\begin{array}{c}\text { (Constant) } \\
\text { Self- }\end{array}$ & 13.917 & 1.529 & & 9.102 & .000 \\
Recognition & .060 & .078 & .069 & .774 & .440 \\
Self-Control & -.126 & .077 & -.151 & - & .102 \\
Motivatio & .010 & .074 & .013 & .140 & .889 \\
Empathy & .058 & .081 & .066 & .714 & .476 \\
Social Skill & -.005 & .062 & -.010 & -.088 & .930 \\
Learning & .175 & .029 & .593 & 6.014 & .000 \\
Behavior & & & & & \\
\hline
\end{tabular}

a. Dependent Variable: Accounting Understanding

\section{Hypothesis Testing Research}

1) Coefficient Determination Test Results (Adjusted $R^{2}$ )

Tabel 2. Multiple Linear Regression Tes Coefficients

\begin{tabular}{|c|c|c|c|c|c|}
\hline \multicolumn{6}{|c|}{ ANOVA $^{\mathrm{a}}$} \\
\hline Model & $\begin{array}{l}\text { Sum of } \\
\text { Squares }\end{array}$ & Df & $\begin{array}{l}\text { Mean } \\
\text { Square }\end{array}$ & $\mathrm{F}$ & Sig. \\
\hline 1 Regression & 242.542 & 6 & 40.424 & 12.282 & $.000^{\mathrm{b}}$ \\
\hline Residual & 434.454 & 132 & 3.291 & & \\
\hline Total & 676.996 & 138 & & & \\
\hline
\end{tabular}

a. Dependent Variable: Accounting Understanding

b. Predictors: (Constant), Self-Recognition, Self Control, Motivation, Empathy, Social Skill, Learning Behavior

Table 3.Coefficient Determination Test Results (Adjusted $\mathrm{R} 2$ )

\begin{tabular}{|r|r|r|c|c|}
\hline Model & $\mathrm{R}$ & $\mathrm{R}$ Square & $\begin{array}{c}\text { Adjusted } \mathrm{R} \\
\text { Square }\end{array}$ & $\begin{array}{c}\text { Std. Error of the } \\
\text { Estimate }\end{array}$ \\
\hline 1 & \multicolumn{1}{|c|}{$599^{\mathrm{a}}$} & .358 & .329 & 1.81420 \\
\hline
\end{tabular}

a. Predictors: (Constant), Self-Recognition, Self Control, Motivation, Empathy, Social Skill, Learning Behavior 
Based on table 3 shows that the $\mathrm{R}$ coefficient score is 0,599 , this shows that self-recognition, self-control, motivation, empathy, social skills, and learning behavior as independent variables have a strong relationship is $59.9 \%$ with accounting understanding as a dependent variable. R2 adjusted Score or the coefficient of determination is used to determine the ability of the independent variable to contribute to the fixed variable. $\mathrm{R} 2$ adjusted score is 0.329 indicates that the independent variables of self-recognition, self-control, motivation, empathy, social skills, and learning behavior can explain variable $32.9 \%$ of accounting understanding, while the remain is $67.1 \%$ explained by others variable outside of this research model. Variable. R2 adjusted Score or the coefficient of determination is used to determine the ability of the independent variable to contribute to the fixed variable. R2 adjusted score is 0.329 indicates that the independent variables of self-recognition, self-control, motivation, empathy, social skills, and learning behavior can explain variable $32.9 \%$ of accounting understanding, while the remain is $67.1 \%$ explained by others variable outside of this research model.

\section{2) Statistical Test Result F (Simultaneous)}

Based on Table 2 we can see sig score is $0.000<\alpha(0.05)$ and $\mathrm{F}$ score which $\mathrm{df}(\mathrm{n} 1)=5$, df $(\mathrm{n} 2)=137$, and sig score is 0.05 obtained table F score is 2.28 . Thus, F score $(12.282)>F$ table (2.28) and sig score is $0.000<\alpha(0.05)$. They show that simultaneously self-recognition, self-control, motivation, empathy, social skills, and learning behavior significantly influence to the accounting understanding.

\section{3) Statistical T-test Result (Partial)}

Tabel 4. Table T-test Result

\section{Coefficients}

\begin{tabular}{|c|c|c|c|c|c|}
\hline \multirow[b]{2}{*}{ Model } & \multicolumn{2}{|c|}{$\begin{array}{l}\text { Unstandardized } \\
\text { Coefficients }\end{array}$} & \multirow{2}{*}{$\begin{array}{c}\text { Standardized } \\
\text { Coefficients } \\
\text { Beta }\end{array}$} & \multirow[b]{2}{*}{$\mathrm{t}$} & \multirow[b]{2}{*}{ Sig. } \\
\hline & B & $\begin{array}{l}\text { Std. } \\
\text { Error }\end{array}$ & & & \\
\hline 1 (Constant) & 13.917 & 1.529 & & 9.102 & .000 \\
\hline $\begin{array}{l}\text { Self- } \\
\text { Recognition }\end{array}$ & .060 & .078 & .069 & .774 & .440 \\
\hline Self-control & -.126 & .077 & -.151 & 1.648 & .102 \\
\hline Motivation & .010 & .074 & .013 & .140 & .889 \\
\hline Empathy & .058 & .081 & .066 & .714 & .476 \\
\hline Social Sklii & -.005 & .062 & -.010 & -.088 & .930 \\
\hline $\begin{array}{l}\text { Learning } \\
\text { Behavior }\end{array}$ & .175 & .029 & .593 & 6.014 & .000 \\
\hline
\end{tabular}

a. Dependent Variable: Accounting Understanding

Based on the test results in table 4, then the partial influence of each independent variable to the dependent variable is described as follows which t table score (139-7) = 132 is 1.978:

- Self-introduction (X1) has t-count score, 0.774 which smaller than t table 1.978 and significance level is 0.440 which bigger than $\alpha(0.05)$. It can be concluded that partially there is no influence between the selfrecognition to accounting understanding
- Self-control (X2) has t-count score, -1.6484 which smaller than t table 1.978 and significance level is 0.102 which bigger than $\alpha(0.05)$. It can be concluded that there is no partial influence between self-control to accounting understanding

- Motivation (X3) has t-count score 0.140, which smaller than t table 1.978 and significance level 0.889 is bigger than $\alpha(0.05)$. It can be concluded that partially there is no influence between motivations to accounting understanding

- Empathy (X4) has t-count score 0.714 which smaller than t table 1.978 and significance level 0.476 is bigger than $\alpha(0.05)$. Therefore, it can be concluded that there is no partial influence between empathy to accounting understanding

- Social skills (X5) have t-count score -0.088 which smaller than t table 1.978 and a significance level 0.930 is bigger than $\alpha(0.05)$. Therefore, it can be concluded that partially there is no influence between social skills to understanding accounting

- Learning Behavior (X6) has t-count score 6.014 which bigger than t-table 1.978 and a significance level 0.000 is smaller than $\alpha(0.05)$. Therefore, it can be concluded that partially there is influence between learning behavior to accounting understanding.

4) Residual Test Result

Table 5. Residual Test result

Coefficients $^{\mathrm{a}}$

\begin{tabular}{|c|c|c|c|c|c|}
\hline \multirow[b]{2}{*}{ Model } & \multicolumn{2}{|c|}{$\begin{array}{l}\text { Unstandardized } \\
\text { Coefficients }\end{array}$} & \multirow{2}{*}{$\begin{array}{c}\text { Standardized } \\
\text { Coefficients } \\
\text { Beta }\end{array}$} & \multirow[b]{2}{*}{$\mathrm{T}$} & \multirow[b]{2}{*}{ Sig. } \\
\hline & B & $\begin{array}{l}\text { Std. } \\
\text { Error }\end{array}$ & & & \\
\hline 1 (Constant) & 11.331 & 3.688 & & 3.073 & .003 \\
\hline $\begin{array}{l}\text { Self- } \\
\text { introduction }\end{array}$ & .223 & .188 & .086 & 1.186 & .238 \\
\hline Self-control & -.189 & .185 & -.075 & 1.021 & .309 \\
\hline Motivation & .915 & .179 & .386 & 5.109 & .000 \\
\hline Empathy & .586 & .194 & .225 & 3.013 & .003 \\
\hline Social Skills & .009 & .150 & .005 & .058 & .954 \\
\hline $\begin{array}{l}\text { Learning } \\
\text { Behavior }\end{array}$ & .286 & .070 & .325 & 4.079 & .000 \\
\hline
\end{tabular}

a. Dependent Variable: Spiritual Intelligence

Table 6. Residual Test result

\begin{tabular}{|c|c|c|c|c|c|}
\hline \multirow[b]{3}{*}{ Model } & \multicolumn{3}{|c|}{ Coefficients $^{\mathrm{a}}$} & \multirow[b]{3}{*}{$\mathrm{T}$} & \multirow[b]{3}{*}{ Sig. } \\
\hline & \multicolumn{2}{|c|}{$\begin{array}{l}\text { Unstandardized } \\
\text { Coefficients }\end{array}$} & \multirow{2}{*}{$\begin{array}{c}\text { Standardized } \\
\text { Coefficients } \\
\text { Beta }\end{array}$} & & \\
\hline & B & $\begin{array}{l}\text { Std. } \\
\text { Error }\end{array}$ & & & \\
\hline 1 (Constant) & 5.607 & 2.195 & & 2.554 & .012 \\
\hline $\begin{array}{l}\text { Accounting } \\
\text { Understanding }\end{array}$ & -.090 & .094 & -.082 & -.961 & .338 \\
\hline
\end{tabular}

a. Dependent Variable: ABSRES_1 
Based on the residual test results in table 5 and table 6 obtained the regression equation as follows:

$$
\begin{aligned}
& \mathrm{Z}=11.331+0.223 \mathrm{X} 1-0.189 \mathrm{X} 2+0.915 \mathrm{X} 3+0.586 \mathrm{X} 4+ \\
& 0.009 \mathrm{X} 5+0.286 \mathrm{X} 6
\end{aligned}
$$

$$
|\mathrm{e}|=5.607-0.090 \mathrm{Y}
$$

A variable can moderate a model of regression if P-Score (Sig) $<0.05$ and its parameter coefficient score is negative. Based on Table 5.10 the residual test results show that the significant score is 0.338 which bigger than $\alpha=0.05$ $(0.338>\alpha=0.05)$ and negative coefficient $(-0.090)$ it can be concluded that spiritual intelligence is not a moderating variable of the relationship between variables self-recognition, self-control, motivation, empathy, social skills, and learning behavior.

\section{5) Discussion of Research Results}

a) The influence of self-recognition to accounting understanding

Partial test results show that the self-recognition has no effect and not significant to accounting understanding. It is showed by the regression coefficient 0.77 is smaller than t table score 1.978 and not significant because sig > t table $(0.440>$ 2.048). This means that the influence of self-recognition is not always along with accounting understanding of students. Selfrecognition of a student does not determine whether good or not the students' understanding in accounting. This is caused that students always analyze actions excessively, and the result the students are not able to recognize the source of strength and skills, especially when studying accounting. This excessive attitude ultimately makes students exaggerate the mind and reactions on certain things, so it can give the negative effects to what is being done or to be achieved. Therefore, all explanations above makes self-recognition have no effect on students' accounting understanding (Goleman, 2016).

b) The influence of self-control to accounting understanding

Test results partially show that self-control has a negative tcount score -1.6484 which $\mathrm{t}$-count score is smaller than $\mathrm{t}$ table 1.978 and significance level 0.102 which bigger than $\alpha(0.05)$. Therefore it can be concluded that there is no partial influence between self-control to accounting understanding. Controlling self excessively will make the student always dampen things what he wants to do, even though it is good for him. Not only that, some students think that self-control is not needed in some ways to achieve something and to satisfy the desires of the heart. These attitudes make many students do negative things in the lecture and their daily activities, so it brings negative result on students' accounting understanding

c) The influence of motivation to accounting understanding

From the partial test, the motivation is concluded that there is no influence between motivations to accounting understanding. Accounting understanding of students does not necessarily increase along with students' motivation. In this case, motivation is kind of psychological elements that will affect all other abilities both expedite and inhibit those abilities. But not infrequently we find that the attitude of encouragement against the heart to do various activities exceed himself make great worry and give a negative thing to his lecture especially to his accounting understanding.

\section{d) The influence empathy to accounting understanding}

Empathy can be concluded that there is no partial influence between empathy to accounting understanding. Empathy for others and they are considered capable of understanding the lessons well and ultimately impacting the students' own understanding. Apparently, empathy does not always give positive effect to accounting understanding. Empathy depends on the experience, perception and ultimately makes different reaction. Understanding the other feelings in association and understanding what we are learning in terms of academics is different. Empathy is showed by understanding other feelings, though learning accounting is not only need feeling sensitivity in feeling, but also understand things materially.

e) The influence of social skills to accounting understanding

Based on the result, partially there is no influence between social skills to understanding accounting. Sometimes we meet some students who want to be a winner in social, want to be considered "exist" so ignore himself, deceive himself and be proud to be a winner in his social. To be a winner in a community that is loved, not infrequently the students ignore the process of learning in the lecture, so impact to learning. Contrary, many smart students who have a good understanding in the subject matter actually become selfish people, feel know everything, ignore others, and do not have good social skills. Because of this, social skill does not have the positive impact to students' understanding in accounting.

\section{f) The influence of learning behavior in accounting} understanding

Actually, there is an influence learning behavior toward accounting understanding. The students' learning behavior such as reading, visiting library, discussing, and preparing himself for exam, make students are more ready to get lecturing. Learning behavior accordances with accounting understanding. If the learning behavior is good, so the students' accounting understanding improve. On the contrary, if the learning behavior is not good, the accounting understanding diminishes too.

g) The Influence Self-recognition, Self-Control, Motivation, Empathy, Social Skills and Learning Behavior toward Accounting Understanding

The results of hypothesis testing simultaneously show that self-recognition, self-control, motivation empathy, social skill, and learning behavior significantly influence the accounting understanding. That is seen from sig score $0.000<\alpha(0.05)$ and $\mathrm{F}$ table which df $(\mathrm{n} 1)=5$, df $(\mathrm{n} 2)=137$, significance score is 0.05 then obtained $\mathrm{F}$ score table equal to 2.28. Thus the $\mathrm{F}$ count score (12.282) $>\mathrm{F}$ table (2.28) and significant score $0.000<\alpha$ (0.05). Therefore, we can conclude that all independent variables simultaneously affected to the dependent variable. 
h) The influence of spiritual intelligence as a moderating variable

The result of the residual test shows negative coefficient (0.090 ) and significant score 0.338 which is bigger than $\alpha=$ $0.05(0.338>\alpha=0.05)$. It means spiritual intelligence is not a moderating variable of relationship between self-recognition, motivation, empathy, social skills, and learning behavior. As we know in each student's self, spiritual intelligence has different level, ultimately impact different reaction. As we know, the learning process is not an easy one, especially if it must be done straightly without breaking the norm. The point here is that students never do mistakes at all, obviously is not an easy process to be done by someone, especially for a student who psychologically in terms of age wants to try many new things regardless of student knowledge and his belief in it. It doesn't mean that every student has a low spiritual intelligence. But in this study, the level of spiritual intelligence of students was not able to strengthen or weaken self-recognition, selfcontrol, motivation, empathy, social skills, and student learning behavior.

\section{CONCLUSIONS, LIMITATIONS AND SUGGESTIONS}

\section{A. Conclusion}

Based on the results of data analysis and discussion that have been done in the previous chapter, this research has conclusions as follows:

1. Simultaneously self-recognition, self-control, motivation, empathy, social skills and learning behaviors have a significant effect on accounting understanding. Partially self-recognition, self-control, motivation, empathy, social skills have no positive effect on accounting understanding. While the learning behavior has a positive affect to accounting understanding

2. Spiritual intelligence is not able to moderate the relationship of self-recognition, self-control, motivation, empathy, social skills, and learning behavior to accounting understanding, because significance score is bigger, although the parameter score is negative.

\section{B. Limitations}

Researchers realize that there are some limitations on this research as follows:

1. This study only discusses the variables that affect the accounting understanding, self-recognition, self-control, motivation, empathy, social skills, and learning behavior. Meanwhile, the adjusted R Square score generated in this study is low, so that there are other variables outside of this research model that can influence the accounting understanding.
2. This research uses survey method, questionnaire. So there is a bias possibility of respondent's answer happened, because of the difference of interpretation to intention and purpose of the question.

3. Taking object study is only done in USU, UNIMED, and UINSU with sample of 139 students.

\section{Suggestion}

Based on the conclusions, the improvements suggested by researchers for further research are:

1. Based on the limitations of this study, for the further researchers who want to observe the accounting understanding is suggested to add other variables associated to accounting understanding, such as intellectual intelligence, confidence, and lecturer competence.

2. The next researcher is expected not only apply the survey method through the spreading of the questionnaire but also do the interview to get more accurate information.

3. The next researcher is hoped to increase the number of samples that are not only three state universities in Medan, but also in private universities in Medan to obtain a more representative results.

\section{REFERENCES}

[1] Mawardi.(2011). "Tingkat Pemahaman Mahasiswa Akuntansi Terhadap Konsep Dasar Akuntansi di PerguruanTinggi di Kota Malang,.JurnalAkuntansiFakultasEkonomiUniversitas Islam Malang (UNISMA).

[2] Goleman, D.(2016). Emotional Intelligence (Edisi Dua puluh Satu).Jakarta : PT GramediaPustakaUmum

[3] Suprianto. E \&Septian H. (2011). "Pengaruh Kecerdasan Emocional, Perilaku Belajar, dan Budaya Terhadap Tingkat Pemahaman Akuntansi Dengan Kepercayaan Diri sebagai Variabel Pemoderasi”'Simposium Nasional Akuntansi XIИ

[4] Ghofur, A. (2013). Tingkat Pemahaman Akuntansi (Studi EMpiris Mahasiswa Akuntansi pada UniversitasSwasta di Lamongan), Jurnal EKBIS, 9(1), 512-516

[5] Irwanto.(2002). PsikologiUmum.Jakarta : PT Prenhalindo

[6] Jamaris,M. (2013). Orienstasi baru dalam Psikologi Pendidikan. Jakarta: Ghalia Indonesia

[7] Suwardjono.(2001)."Memahamkan Akuntansi Dengan Penalaran dan Pendekatan Sistem".Jurnal Ekonomi dan Bisnis Indonesia, 14(3), 106122

[8] Melandy, Rissyo \& Aziza,N. (2006). Pengaruh Kecerdasan Emosional Terhadap Tingkat Pemahaman Akuntansi, Kepercayaan Diri Sebagai Variabel Pemoderasi. Padang. SimposiumNasionalAkuntansi $1 X$.

[9] Rahmi, F.(2013). '’PengaruhKecerdasanEmosional, Kecerdasan Spiritual, dan Perilaku Belajar Terhadap Pemahaman Akuntansi '.JurnalPendidikan Akuntansi. 